\title{
An Analytical Study On Women Working Conditions In Health And Local Government Department Of Karachi
}

\author{
Mussarat Jabeen \\ Women's Studies \\ University of Karachi \\ Nasreen Aslam Shah \\ Department of Social Work \& Women's Studies \\ University of Karachi \\ Faraz Ahmed Wajidi \\ Jinnah Post Graduate Medical Centre \\ Karachi
}

\begin{abstract}
This research has examined the existing status of working women, their problems while performing jobs, working condition and measuring the decision making status at workplace and in their household economy. The study is also analyzed the awareness about pro- women laws, rules, Acts, commitments and conventions signed by Government of Pakistan for empowering women. This research has taken sample of about 117 working women from two public sector departments including health department and local government department in Karachi. The study revealed that most of working women were found in small grade jobs such as nurses, however few were doctors and surgeon. Similarly, majority of them are working in small grade jobs where they earned less as compared to women working at higher posts. It is also observed that women who are educated want to become independent economically, and want to increase their standard of living. It is concluded that they all have been working according to choice and even they do not have any hindrance while performing job, even families are supporting women to work in such departments. In addition, there are very few women who have little knowledge regarding "Protection against Harassment of Women at Workplace Act-2010". Whereas the problems such as lower wage, harassment at work place, supremacy of men do not observed in such governmental departments. The study suggested that there must be provision of facilities to the lower staff or lower grade working women to ensure equality at all levels.
\end{abstract}

Keywords: Working Women, Local Government System, Pro-Women Laws.

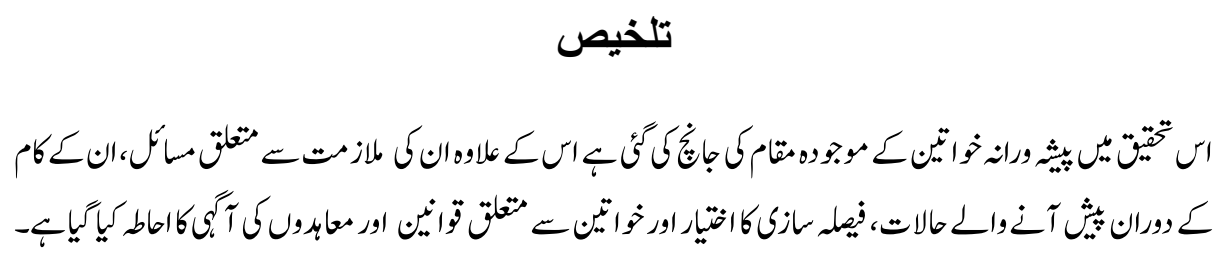




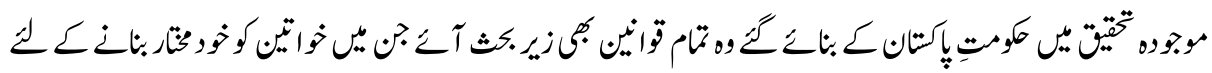

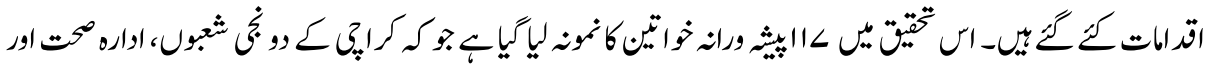

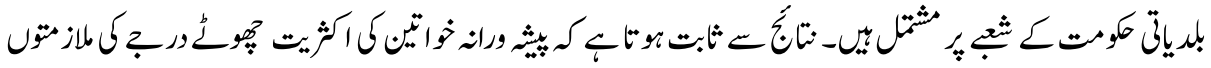

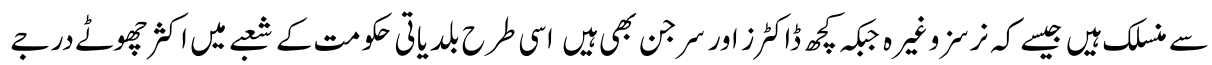

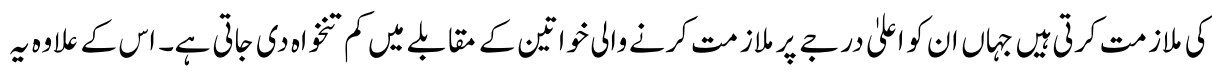

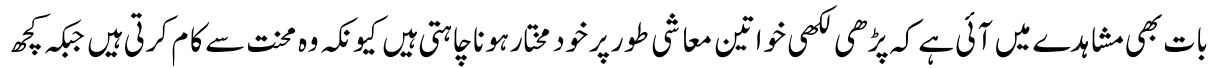

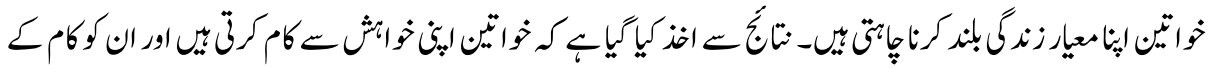

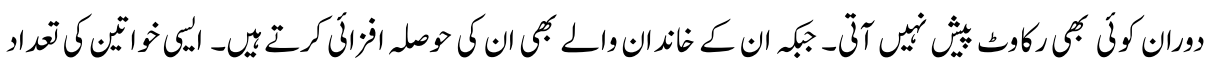

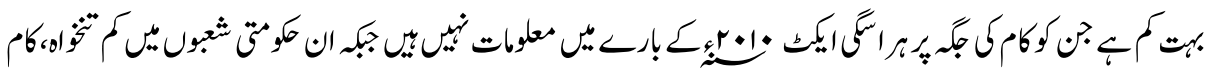

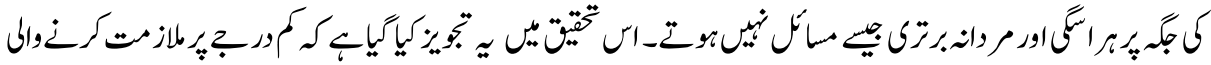

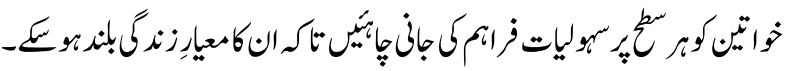

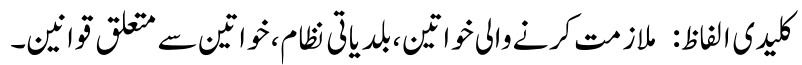

\section{Introduction}

Women economic participation ultimately has positive impacts on achieving gender equality, poverty eradication and of course towards inclusive economic growth. Women are key agents for transformational economic, environmental and social changes required for sustainable development. It also refers to the ability for women to have control over their resources, assets, income and improve their economic status as a whole.

The economic participation of women is recognized globally as essential for the progress of a national and growth of its economy. Indeed this has been recognized in the Government of Pakistan's principal planning documents Vision 2025. The concept of women's economic empowerment (WEE) is a multilayered and complex one that is rooted in context and circumstances. In Pakistan, it is more complex due to the humanitarian crises and complex emergencies that have characterized over past two decade (Women's Economic Participation and Empowerment in Pakistan Status Report, 2016).

As per Global Gender Gap Report 2017 of World Economic Forum has Pakistan is at 143 rank out of 144 countries and found the second worst country in terms of gender parity. The report emphasizes and highlighted on the areas of Global Gender Gap Index 
including economic participation and opportunity, educational attendant, health and survival and political empowerment (World Economic Forum, 2017).

Women in the workforce hold the key to a vibrant economy. Though, Pakistan has seen a turnaround in economic stability, without women's participation in the workforce, the targeted growth will not be achieved. Despite a slow increase in the last 16 years, a mere 22 percent of women (compared to 67.8 percent for men) officially participate in the economic activities. This is the lowest rates of female labour force's participation in the region, however, Afghanistan is standing at second; whereas; women are less in labour force. Similarly, in Vietnam and Bangladesh, the female labour force participation rate is 73 percent and 36 percent, respectively, and women are recognized as a key economic force (Illango \& Caren, 2017).

Similarly, the Sustainable Development Goals (SDGs) adopted by the UN General Assembly in September 2015 recognized the importance of empowering women and said in its goals 5 that there must be equality among all the genders and women or girls should be empowered through delivering basic rights. The targets for this goal aspire to end all forms of discrimination, eliminate violence against women and girls in all its manifestations, ensure health and reproductive rights, ensure political, social and economic participation of women. Targets 5.4, 5a and 5b1 are of particular importance for enabling women's economic empowerment as they relate to acknowledging the value of unpaid care work and domestic work, encourage women's access to land and physical assets and information and communication technology (Alkitkat, 2017).

In addition, Pakistan is signatory of many ILO conventions such as those on equal wages and remuneration, standards of work etc. (Pakistan Decent Work Country Profile 2014). Yet Pakistan does not show good graph on global indicators for women's in economic participation. The Global Gender Gap Report 2015 ranks Pakistan at 143 in economic participation and opportunities, and ranks 135 in educational attainment. These situations, at the bottom of all countries occur despite Article 38 of the Constitution of Pakistan that guarantees citizens the right to pursue economic opportunities irrespective of sex, caste or creed and related labour laws (Women's Economic Participation and Empowerment Status Report, 2016).

It also a bitter reality that the system of male domination over women generates and maintains the social and institutional conditions of male supremacy. Lack of educational development of women produces moral insecurity that makes them psychologically dependent on males, and it causes the feeling of inferiority which further prevents girls from getting education.

It is further elaborated that the subordination of women in all segment of the society causes the psychological problems among women and girls and is accompanied and 
strengthened to material conditions as well, because lack of access to education among women's is hindering towards acquiring paid jobs in the mainstream economy. This would help women to stable economically to become independent and abolish the patriarchal structures of the society (Toossi, 2002).

But even within regions where overall female labor force participation rates are low, there is considerable diversity. In South Asia, female participation rate is about $45 \%$, almost $20 \%$ in Pakistan and $80 \%$ in Nepal, which can be explained by differences in social and economic factors (Antecol, 2000). For instance, women in Nepal are less constrained by social norms, though they work mostly in subsistence agriculture, which is driven more by poverty than by choice. Bangladesh is one of few countries in South Asia that has experienced a rapid increase in women's participation in employment, due to growth in the readymade garment industry and a rise in livestock rearing (linked to access to micro-credit). Despite strong improvements in social indicators, female labor force participation rates in Sri Lanka, a middle-income economy, have remained fairly stable, averaging around 33\% over the decade 2003-2012 (Kolas, 2017).

In Pakistan, women are confronting with four major challenges which includes: increasing literacy among women, access to employment opportunities, promoting changes in the perception of women's role and status and getting public service, in this scenario it is need of time for the government to evaluate concrete measures to enhance the participation of women in work force/employment and by enhancing quota, number of reserved seats, national, international commitments enactment of pro-women laws/acts (National Commission on the Status of Women, 2016).

As far as consequences are concern then most of women are subordinated and tutored by men and lacks in personal and economical autonomy. It is observed that males, husbands, parents or siblings are usually holding the position of head of the family (Charles, \& Grusky, 2005). The World Bank said that it is impossible for most of women to find a job. Around 21 percent percentage of women is under ages of 15 and above are working in paid jobs in different sectors of the economy. According to statistic, about $72 \%$ of women are engaged in agricultural work, $15 \%$ in the service sector and $12.5 \%$ in the industrial sector. Whereas; about 84 percent of males are working in paid work who falls in the age category of above 15 years. The data shows massive discrimination while acknowledging the economic contribution (Roxburgh, 2006).

However, the Government of Pakistan has taken numerous steps and measure for the development and empowerment of women specially for working women, so that they could effectively participate in the mainstream of the economy. In this regard, the government has passed various pro-women Laws, to enhance the job quota of women in all sector, increased number of women seats in National Assembly, Senate and Provincials Assemblies. Number of seats for women is increased in the local government 
system and special seats for women also reserved in local bodies (Maliha, 2013). The government has implemented the "Protection Against Harassment of Women at Workplace Act, 2010" approved by the National Assembly and the government has further taken appropriate actions for implementation of the Act (Khan \& Ahmed, n.d.).

Moreover, the Government of Pakistan is also signatory of several international declarations i.e. Universal Declaration of Human Rights (UDHR), Convention on Elimination of all forms of Discrimination against Women (CEDAW), Millennium Development Goals (MDGs) and other ILO conventions 2000-2002, National Policy for Development and Empowerment of Women which formulated and initiated "Gender Reform Action Plan (GRAP)" and now government is very much committed to get the Sustainable Development Goals and Goal five specially related to gender equality (Kabeer, 2012).

The study is primarily focusing on present provision of gender equality available for various national and international commitments and laws passed by the government for providing the gender equality especially for women. Secondly, how many working women are aware about available laws including Constitution of Pakistan, national and international commitments, women quota in jobs, laws and acts passed by the National and Provincial assemblies, number of seats available for women in Senate, National and Provincial Assemblies.

\section{Review of Literature}

The participation of women in labour force remains low which is at $26 \%$ and the ages fall between 15-64 years, currently women population comprised of approximately 14.4 million in the country. About 41 million women in this age group remain out of the labour force, accounting for $36 \%$ of the entire population (women and men) in the 15-64 age brackets. The percentage of women already employed is highest in the age brackets of $25-59$ years at $70 \%$ is highest, equivalent to approximately eight million women, leaving large numbers of women in this lower age group out of the labour force (Pakistan Economic Survey, 2009-2010).Around 26\% of women are involved in the workforce and in fact they are married; $24 \%$ of these have at least one child less than age three. More women are employed in rural areas than in urban areas, notwithstanding the higher levels of education and presumably better opportunities for work available in towns and cities. About 32 percent of women in the labour force have a college degree or higher, while a similar proportion of women have no education (Majid, 2017). Gender segregation has been observed in occupations with critical mass of $30 \%$ considered to be the tipping point for women in every sector. Women comprise of $39 \%$ of the labour force in the agriculture, forestry, hunting and fishing sector, $22 \%$ in the community, social and personal services sector and $20 \%$ are involved in manufacturing sector. Women working in agricultural 
sector are concentrated in animal production (47\%), followed by mixed farming $(23 \%)$ and growing non-perennial crops (18\%) (PSLM, 2014-2015).

Within occupations, the share of women's employment is high in the category of skilled agriculture and fishery workers (38\%), professionals $(30 \%)$, elementary occupations $(21 \%)$ and crafts and related trades $(18 \%)$. Women in skilled agriculture are concentrated in the sub-category of livestock and dairy producers. Women are concentrated in teaching in primary and secondary education. Few are in the fields of science, technology, engineering or mathematic (STEM). Fewer women found in senior management positions $(0.3 \%)$ or owners of private enterprises (12\%) (Abbas, 2015).

It is available in research data that about $30 \%$ of women and $3 \%$ of men are home-based workers and they have earned total wages of Rs. 400 billion per annum around the globe. Both the genders have contributed about $3.8 \%$ of share in the GDP through the homebased work. It is also observed that home-based workers are engaged in low paid work, without any regulatory framework. In fact there are no benefits healthcare, however; proven productive for the economic growth of the country (Sarim, 2018).

As it is observed that government is signatory of many of the gender equality conventions to overcome discrimination against women, which is considered helpful in attaining sustainable development in the country as a whole. Women representation in public sector departments shows that government is working for ensuring the right of women through giving equal opportunities like men. It is observed that Pakistani women have more presence in politics as compared to other countries of South Asia (Ahmad, 2018).

It is acknowledged that Pakistan has $64^{\text {th }}$ rank in Inter Parliamentary Union's, which highlights that more women have participated in national parliaments which includes senate and provincial assemblies in the country, Pakistan standing at quite better position as far as women political participation is concerned in democratic countries. There are about 342 seats in the national assembly and at present, women comprising of 70 seats in the parliament and 17 percent seats in senate (The Nation, 2016).

The government of Pakistan has also signed and ratified the Convention on Elimination of All Forms of Discrimination against Women (CEDAW) and promised to comply with its provisions and ensure its implementation to secure women rights. It is also said that to strengthen financial status of women, there is a dire need to provide them monetary assistance in a way to empower them. In this regard, Nawaz Sharif government had allocated around 50 percent of loans for women under Prime Minister Youth Loan Scheme, for giving opportunity to work in the mainstream economy of the country and reduce economic imbalances in the country (Hamid, 2018). 
It is important to mention that government is intended to attain gender equality and women empowerment which is one of the Millennium Development Goals for the overall development in social and economic structures of the country. The government is aiming to ensure that women should have presence in all segments and should be sound in all governmental institutions including in judiciary and in the civil services of the country. Women should participate in the private sector of the economy, in order to become a part at business associations to influence the decision making and urged the government to make appropriate gender sensitive policies to ease women in doing business as well. It will have positive impacts in almost every segment of the society.

Unlike many countries Kosovo Police service introduced gender responsive training in their curriculum in 2006, the title "Gender and Border Management" and have team leaders and commanders for the supervision. The training aims to enable security providers to link gender and its matters in daily practices. Training for gender equality is an integral part and should provide at multiple levels and make their presence in the security system for both males and females in all ranks and levels. Trainings also highlighted the gender issues; and had awareness campaigns about sexual harassment at work places faced by women. The training also discussed various issues such as domestic violence, human trafficking, sexual and reproductive health. Such training programs are important to aware women about their due legal rights; as they can have justice through proper procedures including parliamentarians, judges, lawyers, prison personnel, prosecutors and nongovernmental organizations. For effective results gender based trainings need assessments to acknowledge the change through such measures. High ranking personnel also provide capacity building programs and share their valuable experiences for providing guidance for gender awareness and for ensuring gender equality (Mackay, 2008). The reason for mentioning this example of KOSOVO of police service efforts is because we can also initiate such kind of practice in Pakistan to command women that how they can survive or deal with the issues happens at workplaces with women.

It is also a significant point that equality in legislation and national programmes apparently played an effective part in starting and encouraging gender equality activity at the workplace. It is critical to give organizations with chances to share experiences, and in addition to promote, and this should keep continue for further support. As the gender equality plan extends to incorporate race, age, sexuality and religion, there is a risk that diverse disparities may end up stressed as politically essential at various circumstances, to the disadvantage of others. The equality is very important at workplaces as it contributes to ethical, lawful or moral values (Galian \& Etta, 2002).

It is witnessed that gender equality and women empowerment are considered worldwide issue; for this affirmative action numerous formal and informal strategies have been framed around the world. As many studies have revealed the reality in spite of the way that there has been betterment in the status of women as they have become educated and 
working in the economy, but still there are various problems in which violence against women still exist throughout the world. Despite the fact that laws are framed against violence such as imprisonment and fines, but so far no single law is implemented in its true sense (Lather, 2009).

Meanwhile, the MDG's Achievement Fund (2013) had conducted 13 joint programs for Gender Equality and Women's Empowerment and was intended to address the gender issues in wide and all-encompassing way. Generally, the joint programmes have contributed towards the understanding of the common, political, social, and economical privileges and status of women to achieve the MDGs. The programs were conducted in different nations with differing degrees of neediness, poverty and levels of improvement, and also political and socio-economic conditions. The United Nations Development Assistance Framework (UNDAF) organized various program at national and international level for the development of women. However, women empowerment and equality in terms of gender is still very challenging in many countries. In this manner, it is also analysed that cultural and social settings should be altered in the regions for programming with effective mechanism. In several parts of the world, women have no access to resources, rights and privileges as men are entertaining. Around nine joint programs have been conducted for strengthening political and economic empowerment of women For example in Bolivia, e the program concentrated on expanding the financial strengthening which is the most hindering factor for impoverished females, enhancing the lives of an expected 4,640 females by expanding their earnings, and empowering them to help their families and achieve a specific level of financial autonomy. The program emphasized on women's access to resources, economical and educational right, decision making and confidently access to market as entrepreneurs (Rios-Kohn, 2013).

To gain equality in all aspects of life by individuals is actually a fundamental right of every human being which creates civilized societies and ends all forms of oppression against genders in the world. Especially women is considered the most deprived gender in all the segments of life; as they do not have equal access of getting education, suffering from malnutrition as lacking health care facilities, as there are lesser opportunities of work in the labour force for women. However if they have been given equal rights in all such mentioned sectors then she can be able to take part in politics and may also economically active in the country. As education and employment will restore their confidence and as it is a general perception that person dominates when they start earning and also gain power so, they will also become a part of decision making process at national levels. The country has signed various developmental projects of the United Nations, one of them is Sustainable Development Goals (SDGs) in a way to bring gender equality and focus on delivering equal rights for improving women socio-economic conditions.

In addition country's National Plan of Action, National Policy for Development are emphasizing to empower women with their consistent efforts as trying to comply with 
international gender commitments. For last 18 years, several legislations have been made against gender-based violence in Pakistan. In fact different schemes have been evolved to facilitate women under such policies which are as under:

- 'Youth Business Loan Scheme' has reserved and allocated 50\% of loans for women.

- 'Minister's Youth Skill Development Scheme' trained women through vocational trainings and skills, however around 800 million rupees have been allocated by the government under this scheme.

- At present 'Sindh Government's Landless Haris Project' beneficiaries are most of women, which is about 70.6 percent of land titles given to women living in rural areas.

- The federal government has fixed 10 percent of quota in civil services for women.

- The Punjab government has launched a project 'Punjab Fair Representation of Women Act 2014'which is allocated around 33\% of representation in all statutory or public organizations of the country.

- Women desks have been set up at federal and provincial level for implementing the harassment act by all means possible, even various workshops and seminars were conducted to aware women about preventive laws from violence.

- To empower women economically around 2.7 billion rupees are projected to be allocated; while explain eleven year program (Pakistan Economic Survey, 2016-17).

\section{Objectives of the Study}

- To observe the problems faced by women at workplace in public sector institutions, Karachi (in health and local government department).

- To find out ways for improving the existing working condition for women in public sector institutions.

- To highlight existing laws which are framed for the protection of working women in governmental sector.

- To find out whether working women are aware about national and international commitment, legislations signed by the government for their protection.

- To find out what facilities are available for working women in health and local government departments.

- To find out gender biasness in the promotion of male and female worker.

- To identify social, and cultural, challenges faced by professional women.

- To find out whether working women are aware about national and international commitment, legislations signed / passed by Government from time to time for their protection.

- To acknowledge that women are getting benefit from these laws in governmental institutions. 


\section{Methodology}

This research is carried out in two governmental sectors of Sindh i.e. health public institutions and local government body. The research highlights employment patterns (position/post) of women, and their improvement in their standard of living and human development ratio in such organizations. This research has examined the problems of working women in two government department and their level of awareness about various initiatives taken by government for betterments of working women; as stable economic conditions for women not only to stable their families' income but also to contribute to the national economy. The present research is a descriptive research and highlights the existing and laws regarding working women in the country and its implementation. The research has used quantitative methods and has conducted a survey in health and local government departments, where the sample size of working women is one hundred and seventeen (117). Interviews were used as a tool for data collection from working women of two government departments in Karachi: The universe or population was taken from local government bodies which are as under: Secretariat, Directorate of Local Government, Field Offices, Karachi Metropolitan Corporation (KMC), District Municipal committees (DMCs), District Council Karachi, Union council and union Committees). Health department includes the following hospitals: Secretariat, D.G office, Directorate, Civil Hospital Karachi, Sindh Government Hospital Liaqatabad and Sindh Government Qatar Hospital Karachi.

\section{Results and Discussion}

The Government of Pakistan as well as the Government of Sindh has recognized the present position of women in the public sector and also targeting to achieve Sustainable Development Goals especially gender equality, and on cross cutting themes, to give more employment opportunities in various sectors i.e. women in informal sector, enhance the quota of women in all types of employment, and women in agriculture. As various agricultural policy have been framed, wherein women are given special attention, homebased workers for which labour department, Government of Sindh with the approval of Chief Minister Sindh announced the first ever home-based women workers policy for women in business especial loan through commercial and non-commercial banks and institution, as the mark up over loan is on very low rate for women and other bills like equal pay for equal work has also passed; these efforts made by the government and various NGOs, though the participation of women in workforce is still far behind.

The research data is analysed the problem of working women in two government department in terms of their ages, work experiences, salary, marital status, family structure, available facilities, and their level of awareness about various initiatives taken by the government for their betterment. The study has combined both governmental departments' women workers data to analyze women's work profile, awareness of laws, and women working conditions of the research sample. 


\section{Demographic Profile}

Table: 1

Distribution of respondents according to their designation

\begin{tabular}{|l|c|c|}
\hline Designation & Frequency & Percentage \\
\hline Nurse & 62 & $52.90 \%$ \\
\hline Teacher & 4 & $3.41 \%$ \\
\hline Senior Women Medical Officer/ Doctor & 18 & $15.38 \%$ \\
\hline Receptionist & 10 & $8.54 \%$ \\
\hline Lab attendant / Radiographer & 10 & $8.54 \%$ \\
\hline Medical Assistant & 1 & $0.85 \%$ \\
\hline Aya & 10 & $8.54 \%$ \\
\hline Surgeon & 1 & $0.85 \%$ \\
\hline Director Information & 1 & $0.85 \%$ \\
\hline Total & $\mathbf{1 1 7}$ & $\mathbf{1 0 0 \%}$ \\
\hline
\end{tabular}

The above table shows the designation of the respondent that there are about nine different category of designation from Aya to medical surgeon. The largest respondent are nurses which comprising of $52.9 \%$, about $15.38 \%$ are doctor or senior women medical officer and 8.54\% respondents are receptionist/Aya and lab attendant. In this study most of women are engaged in nursing profession, as nursing is most respectful job for female and it is a dignified job, as nurses are devoted and provide better services to patient besides, they have middle level education, therefore $52 \%$ of female are in nursing field in total sample of the study.

Table: 2

Distribution of respondents according to their organization/ institution

\begin{tabular}{|l|c|c|}
\hline Organization & Frequency & Percentage \\
\hline KMDC Hospital Local Government & 10 & $8.54 \%$ \\
\hline Civil Hospital /Dow Medical University & 61 & $52.13 \%$ \\
\hline Jinnah Hospital & 4 & $3.41 \%$ \\
\hline Welfare Organization & 1 & $0.85 \%$ \\
\hline Sindh Govt. Hospital Liaquatabad & 24 & $20.51 \%$ \\
\hline Sindh Government Qatar Hospital & 10 & $8.54 \%$ \\
\hline $\begin{array}{l}\text { Monitoring \& Evaluation Cell Local } \\
\text { Government Sindh }\end{array}$ & 2 & $1.70 \%$ \\
\hline Sheikh eye Hospital & 1 & $0.85 \%$ \\
\hline School KMDC Local Government & 4 & $3.41 \%$ \\
\hline Total & $\mathbf{1 1 7}$ & $\mathbf{1 0 0 \%}$ \\
\hline
\end{tabular}

The table shows that $52.13 \%$ of respondents working in Civil/Dow Hospital, $20.51 \%$ in Sindh Government Hospital Liaquatabad and $8.54 \%$ in Sindh Government, Qatar 
Hospital and KMDC Hospital in local government. There are very few women working in local government department at highest post including Secretariat, Directorate and its field offices level. Therefore only 3.4\% women respondents in this survey have taken from schools in local government and around 1.7\% are from monitoring and evaluation cell of local government department Sindh.

Table: 3

Distribution of respondents according to their age group

\begin{tabular}{|l|c|c|}
\hline Age & Frequency & Percentage \\
\hline 20-30 Years & 26 & $22.22 \%$ \\
\hline 31-40 Years & 33 & $28.20 \%$ \\
\hline $41-50$ Years & 27 & $23.07 \%$ \\
\hline $51-60$ Years & 30 & $25.64 \%$ \\
\hline 60 and above & 1 & $0.85 \%$ \\
\hline Total & $\mathbf{1 1 7}$ & $\mathbf{1 0 0 \%}$ \\
\hline
\end{tabular}

The above table describing the age of respondents in which the majority of working women in the local government and health sector are in age group of 31-40 years which contain $28.20 \%$ of total respondents, $25.64 \%$ are falling in 51-60 years category and $23.07 \%$ are of $41-50$ years of age. Most of the respondents are of 31-40 years of age because these age people apply for more job. Since the study conducted in government sector, only $0.85 \%$ of women are of 60 years and above, as old age people do not get jobs easily.

The research also revealed that women of age group 20-30 are only $22.22 \%$, in fact their appointment are in process and working women are available almost with equal proportion (22\% to $28 \%$ ) in all age groups. However, government should increase the female appointments on vacant posts and encourage female to join the government sector through evolving massive opportunities.

Table: 4

Distribution of respondents according to their family structure

\begin{tabular}{|l|c|c|}
\hline Family Structure & Frequency & Percentage \\
\hline Nuclear & 40 & $34.18 \%$ \\
\hline Joint & 77 & $65.81 \%$ \\
\hline Total & $\mathbf{1 1 7}$ & $\mathbf{1 0 0 \%}$ \\
\hline
\end{tabular}

Family structure played vital role for both men and women throughout their lives on their social and economic life. Mostly men and women commonly live with their parents until they get married, and even after marriage they continue to live in the joint family system, i.e., with the husband's family. Despite of many changes occur, the institution of the 
family (Khandan) plays a very important role for women and especially for working women either lives in urban or rural area. In the present study, the family structure of working women in two government department are also studied which reveals that $65.81 \%$ of working women mostly married and unmarried and preferred to live in joint family system while $34.18 \%$ are living in nuclear family system. Most of the respondents want to live in joint family system, as in joint family especially when women is under employment could share most of their domestic work, caring of children and adult.

Table: 5

Distribution of respondents according to their marital status

\begin{tabular}{|l|c|c|}
\hline Marital Status & Frequency & Percentage \\
\hline Single & 26 & $22.22 \%$ \\
\hline Married & 81 & $69.23 \%$ \\
\hline Widowed & 7 & $5.98 \%$ \\
\hline Divorced & 3 & $2.56 \%$ \\
\hline Total & $\mathbf{1 1 7}$ & $\mathbf{1 0 0 \%}$ \\
\hline
\end{tabular}

The above table showed the marital status of working women interviewed during the study. As marital status is the most important aspect which has increased the responsibilities for working women. In our culture married women are prefer to work at home and doing their domestic chores besides single, widow or divorced women manage to work in order to earn and to contribute in their family income. But this study sample shows very different results as $69.23 \%$ of total women are married whereas $22.22 \%$ single, $2.56 \%$ of divorced and $5.98 \%$ widowed women. The data shows that the respondents who work in local government and health sector are mostly married due to facilities of governmental jobs women are preferred to continue their job even after their marriage. It is recorded that total 91 women respondents have children in the sample, in which $61.5 \%$ women have $3-4$ children, $21.9 \%$ have $5-6$ children and $10.9 \%$ have $1-2$ children. It is observed that birth of children did not create any hindrance for women to get out of jobs because families and spouses are supporting and willing that they should continue government jobs. Besides this, women responded that few challenges they have to face in form of double burden in a way to work in private and public life, but anyhow they manage their work and life, and also added that their income supports to have better education for their children and for raising their living standards. It reflects from respondents opinions that in these two sectors married women are easily manage their household responsibilities with the support of family and in laws as well. 
Women's Work Profile

Table: 6

Distribution of respondents according to their work experience

\begin{tabular}{|l|c|c|}
\hline Duration & Frequency & Percentage \\
\hline 6 months to 5 years & 24 & $20.51 \%$ \\
\hline 6 years to 10 years & 30 & $25.64 \%$ \\
\hline 11years to 15 years & 32 & $27.35 \%$ \\
\hline Above 15 years & 31 & $26.49 \%$ \\
\hline Total & $\mathbf{1 1 7}$ & $\mathbf{1 0 0 \%}$ \\
\hline
\end{tabular}

The survey observed that the majority of working women have 11 to 15 years of experience which contained 27.35\%; while $26.49 \%$ are working for last 15 years and more. Around $25.64 \%$ of women are working in hospitals and government department for 6 to 10 years. Most of the respondents work for many years as compared to other in order to fulfil their financial needs. The table further showed that in all categories of working experience the gap is very narrow; women are continuously entering into new jobs in government sector on regularly basis.

Table: 7

Distribution of respondents according to their monthly income

\begin{tabular}{|l|c|c|}
\hline Monthly income & Frequency & Percentage \\
\hline $1000-10,000$ & 40 & $34.18 \%$ \\
\hline $10,001-20,000$ & 9 & $7.69 \%$ \\
\hline $20,001-30,000$ & 12 & $10.25 \%$ \\
\hline $30,001-40,000$ & 10 & $8.54 \%$ \\
\hline $40,001-50,000$ & 12 & $10.25 \%$ \\
\hline $50,001-60,000$ & 2 & $1.70 \%$ \\
\hline $60,001-70,000$ & 2 & $1.70 \%$ \\
\hline $70,001-80,000$ & 15 & $12.82 \%$ \\
\hline $80,001-90,000$ & 7 & $5.98 \%$ \\
\hline $90001-100,000$ & 3 & $2.56 \%$ \\
\hline $100,001 \&$ above & 5 & $4.27 \%$ \\
\hline Total & $\mathbf{1 1 7}$ & $\mathbf{1 0 0 \%}$ \\
\hline
\end{tabular}

The data shows that the monthly income of the working women respondent is started from Rs 1000-10,000/-and with the difference of Rs 10,000/- ended at Rs 100,000/- and more. The problems of working women are covered from Aya, attendant to surgeon and director therefore, variations and vast difference in monthly pays also noticed in the study. The table mentioned that $34.18 \%$ of working women are earning Rs 1000 to 10,000 , 
about $12.82 \%$ are earning Rs 70,001 to 80,000 monthly and around $10.25 \%$ earn 20,001 to 30,000 and $40,001-50,000$. While only $4.27 \%$ women get monthly income Rs.100,000 and above. It is very much obvious that mostly working women in government jobs are working on small scale / grade / positions and very low percentage of women are working in higher positions.

Awareness about Legislations

Table: 8

Distribution of respondents that they aware about national and international legislation for protection of working women

\begin{tabular}{|l|c|c|}
\hline Aware about legislation & Frequency & Percentage \\
\hline Yes & 24 & $20.51 \%$ \\
\hline No & 93 & $79.49 \%$ \\
\hline Total & $\mathbf{1 1 7}$ & $\mathbf{1 0 0 \%}$ \\
\hline
\end{tabular}

The Government of Pakistan has taken measure for the development and empowerment of women; as country is signatory of several international declarations and treaty i.e. Universal Declaration of Human Rights, signatory to ratification of Convention on the Elimination of all forms of Discrimination against Women (CEDAW), Millennium Development Goals and other ILO conventions 2000-2002, and now government is very much committed to get the Sustainable Development Goals 'five'. Several laws passed by federal and provincial government which are directly related to working women i.e. "Protection against Harassment of Women at Workplace Act, 2010" Women Pregnancy Leave Act 2015 and others. In addition, the current survey in governmental departments showed that about $79.49 \%$ of respondents are not aware about any of such legislation and commitment of government and $20.51 \%$ are known about few legislations. Majority of the respondents do not aware about legislation because lack of education and interest.

Table: 9

Distribution of respondents that they aware about Harassment Act 2010

\begin{tabular}{|l|c|c|}
\hline Aware about Act & Frequency & Percentage \\
\hline Yes & 30 & $25.64 \%$ \\
\hline No & 87 & $74.35 \%$ \\
\hline Total & $\mathbf{1 1 7}$ & $\mathbf{1 0 0 \%}$ \\
\hline
\end{tabular}

The Government of Pakistan has approved the Act titled, "Protection against Harassment of Women at the workplace Act, 2010. The purpose of this Act is to provide safe and secure working environment to women at workplace. To ensure implementation of this Act in its true spirit government has made its mandatory for all public and private sectors including educational institutions to adopt the "code of conduct" in the institution to 
comply with the Act. "Protection against Harassment of Women at Workplace Act, 2010". The intention of the law is to provide an opportunity to all organizations, institutions, public, private and civil society to develop a self-regulatory mechanism whereby organizations / institutions can handle the problems related to sexual harassment internally. Implementation of this code has become mandatory for all organizations / institutions.

In Sindh, the law is enacted and a separate office of ombudsperson has been established. More than 2500 enquiry committees are established throughout the province. Above table shows that $74.35 \%$ of respondents are not aware about the Sexual Harassment Act 2010 and $25.64 \%$ are aware about this Act. Majority of the respondent don't know about harassment act, as in hospitals there is no enquiry committee against harassment if faced by any of women.

Table: 10

Distribution of respondents that required training regarding for improvement of their work

\begin{tabular}{|l|c|c|}
\hline Training & Frequency & Percentage \\
\hline Yes & 59 & $50.42 \%$ \\
\hline No & 58 & $49.57 \%$ \\
\hline Total & $\mathbf{1 1 7}$ & $\mathbf{1 0 0 \%}$ \\
\hline Capacity building already taken & \multicolumn{2}{|l|}{} \\
\hline Yes & 22 & $18.80 \%$ \\
\hline No & 95 & $81.19 \%$ \\
\hline Total & $\mathbf{1 1 7}$ & $\mathbf{1 0 0 \%}$ \\
\hline
\end{tabular}

In order to improve the job skills and to enhance the capacity of employees on job training or training at workplace are provided to employees or workers. Theses training not only enhance their knowledge and skills, but also essential to perform adequate performance on the job.

Job training is also one of the major steps for specific posts in health and local government department, Karachi. Health department required time to time job trainings by officer and official in managerial/administrative field for better administration while doctors, nurses, technician, and other Para-medical staff consecutively needed capacity building skill and improvement in handling new technologies at hospitals. In local government department, officer and official field staff, data processing assistant and others are obliged to perform training as per their job requirements. 
The data revealed that around $50.42 \%$ of respondents is required training for improvement at their workplace and $49.57 \%$ have informed that no training required for making improvement in their existing performing task.

It is also observed that health and local government departments have spent huge amount for capacity building training for employee in order to improve their performance and professional skills. But the result in the present study is varying that about $18.30 \%$ said that government has provided training program/workshop for capacity building of working women while $81.19 \%$ of respondents does not received any kind of training by governmental departments. Even the majority of women responded that they do not know about any of governmental plans for capacity building for working women.

\section{Women Working Conditions}

The research paper has explored women working conditions on the basis of reasons why women are working, facilities they get at workplace, do they pressurise for performing job, women working grades and cadres in public sector jobs, assess the condition whether timely promotions given to women or not, or to observe the discrimination on such grounds.

Table: 11

Distribution of respondents according to their reason of work

\begin{tabular}{|l|c|c|}
\hline Reason of work & Frequency & Percentage \\
\hline Wanted to be independent & 26 & $22.22 \%$ \\
\hline Wanted to lead a purposeful life & 10 & $8.54 \%$ \\
\hline Wanted to achieve a status & 3 & $2.56 \%$ \\
\hline Just to full fill passion / wish & 20 & $17.09 \%$ \\
\hline Have nothing better than this & 13 & $11.11 \%$ \\
\hline Govt. Job/ Financial problem & 45 & $38.46 \%$ \\
\hline Total & $\mathbf{1 1 7}$ & $\mathbf{1 0 0 \%}$ \\
\hline
\end{tabular}

The above table briefly explained reason of work among women in two of government sector i.e. health and local government department in Karachi. Around $38.46 \%$ of working women stated that they are doing this job because they have government job and they are receiving the benefits of leave and security, however their guardians husband / father and other family member feels that government job is respectable and safe place for job, and have other reasons like to support their families, around $22.22 \%$ of women doing work as they wanted to be independent and $17.09 \%$ work to fulfil their passion /wishes while $11.11 \%$ responded that they have nothing better than doing work. Around $8.54 \%$ of the view that they want to spend a purposeful life. Lastly $2.56 \%$ women want to have high standard of living. 
Table: 12

Distribution of respondents what facilities they get at workplace

\begin{tabular}{|l|c|c|}
\hline Facilities & Frequency & Percentage \\
\hline Medical & 15 & $12.82 \%$ \\
\hline Residence & 4 & $3.41 \%$ \\
\hline Conveyance & 8 & $6.83 \%$ \\
\hline All Allowances & 16 & $13.67 \%$ \\
\hline Uniform & 15 & $12.82 \%$ \\
\hline Lunch & 4 & $3.41 \%$ \\
\hline Not aware about Facilities & 10 & $8.5 \%$ \\
\hline None & 45 & $38.46 \%$ \\
\hline Total & $\mathbf{1 1 7}$ & $\mathbf{1 0 0 \%}$ \\
\hline
\end{tabular}

The available facilities for the working women in two government sector i.e. health and local government department in Karachi at their workplace with regards to medical, residence, conveyance, allowance, uniforms, lunch and other. It is mentioned that in government jobs all allowance are provided with salaries therefore, mostly employees are not known whether they get any facility or not; about $38.46 \%$ respondents answered that they do not get any facilities and $8.5 \%$ sated that they do not aware about any facility. On the other hand $13.67 \%$ admitted that they get all the allowances. In government departments uniforms are provided to the lower officials including Aya and nurses i.e. $12.82 \%$ especially in health department. About $12.82 \%$ respondents agreed they have medical facilities. Whereas $6.83 \%$ said that they get conveyance facilities, $3.41 \%$ get lunch facilities at their working place while some working women also have residence facilities $(3.41 \%)$.

Table: 13

Distribution of respondents regarding father/brother/husband/pressurize to do work

\begin{tabular}{|l|c|c|}
\hline Pressure & Frequency & Percentage \\
\hline Yes & 70 & $59.82 \%$ \\
\hline No & 47 & $40.17 \%$ \\
\hline Total & $\mathbf{1 1 7}$ & $\mathbf{1 0 0 \%}$ \\
\hline
\end{tabular}

In current economic situation both men and women have to play its role in contributing family income. In some cases wives or daughters realized that if families are facing financial hardship then females decide to perform job and provide supplement to their family income. In some families especially in civilized societies where daughters are given equal opportunities of education then after completing education; fathers, brothers and husbands sometime give equal chances to do work / job or pressurize women to do some job and contribute to the family income. Above table shows that $59.82 \%$ of 
respondent's father/ brother/ husband pressurize them to do work and $40.17 \%$ do not pressurize them to do work.

Table: 14

Distribution of respondents they think that workplace conditions are suitable for women in formal sector

\begin{tabular}{|l|c|c|}
\hline Working conditions & Frequency & Percentage \\
\hline Yes & 47 & $40.17 \%$ \\
\hline No & 70 & $59.82 \%$ \\
\hline Total & $\mathbf{1 1 7}$ & $\mathbf{1 0 0 \%}$ \\
\hline
\end{tabular}

Although the study has been conducted in the formal sector of two government department i.e. health and local government department in Karachi, but majority of women are not satisfied with working environment. The above table shows that $59.82 \%$ of respondents do not satisfied with their working conditions, and informed that condition is not suitable for them even in formal sector and about $40.17 \%$ of respondents stated that their working conditions are suitable for women as working in the formal sector of the economy. It was observed during the study that basic facilities are available for female staff in higher grades i.e. lady doctors, executive staff, but not for nurses, midwives, and Ayas. Facilities include separate common room, washroom, prayer room and others.

Table - 15

Distribution of respondents according to the grades of total vacancies of male and female in local government department of Sind

\begin{tabular}{|l|c|c|c|c|c|c|c|}
\hline Grade & \multicolumn{2}{|c|}{ Male } & \multicolumn{2}{c|}{ Females } & \multicolumn{3}{c|}{ Total } \\
\hline & Frequency & Percentage & Frequency & Percentage & Total & Male \% & Female \% \\
\hline $1-5 B P S$ & 2000 & $27.68 \%$ & 125 & $38.94 \%$ & 2125 & 94.448 & 5.882 \\
\hline $\begin{array}{l}6-10 \\
\text { BPS }\end{array}$ & 1900 & $26.305 \%$ & 46 & $14.33 \%$ & 1946 & 97.636 & 2.364 \\
\hline $\begin{array}{l}11-15 \\
\text { BPS }\end{array}$ & 1524 & $21.09 \%$ & 100 & $31.15 \%$ & 1624 & 93.842 & 6.158 \\
\hline $\begin{array}{l}16-20 \\
\text { BPS }\end{array}$ & 1800 & $24.91 \%$ & 50 & $15.49 \%$ & 1850 & 97.297 & 2.703 \\
\hline Total & 7224 & $100 \%$ & 321 & $100 \%$ & 7524 & 96.013 & 4.266 \\
\hline
\end{tabular}

(Data compiled by the author)

Above table shows that $27.68 \%$ vacancies for males is of $1-5 \mathrm{BPS}, 26.30 \%$ is of $6-10 \mathrm{BPS}$ and $24.91 \%$ is of $16-20 \mathrm{BPS}$. However, around $38.94 \%$ females vacancies is of $1-5 \mathrm{BPS}$, $31.15 \%$ is of $11-15$ BPS and $15.49 \%$ is of $16-20$ BPS in Local Government Department of Sindh. 
In total women are higher ration in BPS (1 to 5) which constitute 5.88\% while in BPS (16-20) Women are only $2.7 \%$ in all grades women in local Government $4.2 \%$ in the above table result shows that vacancies for females are very less as compare to males. This shows that women are discriminated in all the grades as in Local Government Department of Sindh.

Table-16

Distribution of respondents according to their post's promotion on next Cadre

\begin{tabular}{|l|c|c|}
\hline Promotion on next Cadre & Frequency & Percentage \\
\hline Yes & 89 & $76.06 \%$ \\
\hline No & 28 & $23.94 \%$ \\
\hline Total & 117 & $100 \%$ \\
\hline
\end{tabular}

The table shows the case of two government departments in health and local government department where women respondents working on promotional post where mostly promotions in next cadre /grade has been provided without any discrimination as above table shows that $76.06 \%$ respondents have post for promotion on next cadre and $23.04 \%$ are not working on promotion posts.

Table-17

Distribution of respondents do they feel their male colleague promoted early

\begin{tabular}{|l|c|c|}
\hline Male Colleague Promotion & Frequency & Percentage \\
\hline Yes & 24 & $20.52 \%$ \\
\hline No & 93 & $79.48 \%$ \\
\hline Total & 117 & $100 \%$ \\
\hline
\end{tabular}

The above table indicated the gender balance situation while have promotions as $79.48 \%$ respondent's think that their male colleague does not get promotion early and $20.52 \%$ get promotion early because of various reasons such as they are more competent, hardworking and having good relation with their bosses.

\section{Conclusions}

The conclusion has been drawn on the basis of acquired results, which shows that numbers of women are found in public sector jobs including local government and health sectors as government jobs are providing several facilities to their employees. It is observed usually traditional societies do not allow women to work for earning income to keep women suppressed so that men can maintain their dominance in the society. But now due to the changing economic trends, the women workers informed that their male counterparts allow them to work, and about quarter of them responded that they are 
pressurized not to leave government jobs. It is very unique kind of information explored from this study that these women manage household economy also, in addition supporting their family financially as well. However, another significant point highlighted that educated families want to make their women economically independent.

According to women respondents they are working in very good condition, as there are no incidents of harassment recorded, or any favours asked by the male bosses from their female workers, even majority of female employees agreed that they get promotions easily and further admitted that if males are getting promotions earlier so, they are competent and have capabilities to perform well. In fact, there are no pay gap issues found in public sector employment among men and women.

But under such positive scenario, few thing are found discriminatory, which are that is glass ceiling among female government employees, as the high ratio of women is found in lower grades and cadres as compared to the higher posts. Whereas, female respondents believed that women cannot contest for the male posts due to many reasons including paternal and benevolent system of our society. On the other hand, it is also very bizarre that majority of females are unaware about national and international pro-women laws in a way to demand their due rights. However, if women are aware about all the laws related to women, then only women can move forward to achieve higher levels of development in the economy.

\section{Recommendations}

- Government should ensure implementation of Sexual Harassment Act 2010 at all workplaces to ensure violence free working place for women.

- The basic facilities should be given to the lower staff as well including to nurses, midwives, and Ayas, as other upper strata of the staff is availing.

- The Government of Sindh Labour Department has passed Pregnancy leave Act which should be used effectively and strictly by the employees.

- $\quad$ Government should make necessary measures for the publicity and awareness of pro-women laws/acts in general public so that more women could be benefited and take part in economic activities of the country.

- There must be massive advertisements for women employments in local government system, to encourage and bring women out from stereotypical jobs.

- The training programs at various cadres and post required, which should be given to women before hiring as they can become professionally skilled and would give maximum output at the workplace. 


\section{References}

Abbas, Mhosin (2015). Trend of Occupation Injuries/Diseases in Pakistan: Index Value Analysis of Injured Employed Persons from 2001-02 to 2012-13, Safety and Health Work Journal, vol.6:3, p.222.

Ahmad, Iftikhar. (2018). No Country for Working Women, The Express Tribune, retrieved from: https://tribune.com.pk on July 20, 2018.

ALkitkat, Huda. (2017). Egyptian Female Labor Force Participation and the Future of Economic Empowerment, Springer, Switzerland, p.9.

Antecol, H. (2000). An Examination of Cross-Country Differences in the Gender Gap in Labor Force Participation Rates. Labour Economics, vol.7:4, pp.409-426.

Charles \& Grusky (2005). Occupational Ghettos: The Worldwide Segregation of Women and Men, Stanford University Press, USA.

European Commission (1996a). Fourth Medium-Term Community Action Programme on Equal Opportunities for Men and Women 1996-2000 (COM (96) 67 final), Luxembourg, Office for Official Publications of the European Communities.

Gillian. G \& Etta. O. (2002). Promoting Gender Equality in the Workplace: Office for Official Publications of the European Communities, Luxembourg.

Hamid, B., Sugata, M. \& Suryaprakash, M. (2017). Inequality, Structure of Production and International Trade, the Role of Credit Market in Developing Countries, CES Working Papers, Services 6307, CES group Munich.

Illango, Patchamuthu \& Caren, Grown (2017). Women In the Workforce, Business Recorder. Retrieved from: https//:www.businessrecorder.com on February 8, 2017.

Kabeer, N. (2012). Women's Economic Empowerment and Inclusive Growth: Labour Markets and Enterprise, School of Oriental and African Studies, UK SIG.

Khan, M. \& Ahmed, A. (2016). A Legislative Review: The Protection against Harassment of Women at the Workplace Act 2010, LUMs Law Journal, vol.3:1.

Kolas, Ashild. (2017). Women, Peace and Security in Nepal: From Civil War to Post Conflict Reconstruction, Rutledge, New York. 
Lather, P. (2009). Scientific Research in Education: A Critical Perspective. British Luxembourg: Office for Official Publications of the European Communities.

Mackay, Angela (2008). Border Management and Gender in Megan Bastick and Kristin Valasek (eds.), Gender and Security Sector Reform Toolkit, DCAF, UNINSTRAW, OSCE/ODIHR, Geneva.

Majid, Hadia (2017). Where are the women, Dawn Newspaper. Retrieved from: https://www.dawn.com on July 20, 2018.

National Commission on the Status of Women (2016). Inquiry into the Status of Women in Public Sector Organizations, Islamabad, Government of Pakistan.

Pakistan Economic Survey (2009-2010). Islamabad: Ministry of Finance, Government of Pakistan. Retrieved from: http://www.finance.gov.pk/ survey_0910.html on 17 July, 2017.

Pakistan Economic Survey (2015-16). Islamabad: Ministry of Finance, Government of Pakistan. Retrieved from: http://www.finance.gov.pk/survey_1617.html on 20 July, 2018.

Pakistan Economic Survey. (2016-17). Islamabad: Ministry of Finance, Government of Pakistan. Retrieved from: http://www.finance.gov.pk/survey_1617.htmlon July 20, 2018.

PSLM. (2014-15). Pakistan Social and Living Standards Measurement Survey http://www.pbs.gov.pk/sites/default/files/pslm/publications/

PSLM 201415_National-Provincial-District_report.pdf

Rios- Kohn, Rabeca. (2013). Gender Equality and Women's Empowerment MDG-F, Thematic Study: Review of Key Findings and Achievements: MDG Achievement Fund.

Roxburgh, S. (2006). "I wish we had more time to spend together...", The Distribution and Predictors of Perceived Family Time Pressures among Married Men and Women in the Paid Labor Force. Journal of Family Issues, vol.27:4, pp.529-553.

Sarim, Maryam (2018). Pakistan for Women, The Express Tribune. Retrieved from: https://www.tribune.com.pk on July 20, 2018. 
The Nation (2016, March 14). 20\% Women MPs Responsible for 44\% Parliamentary Business. Retrieved from: https://nation.com.pk on July 20, 2018.

Toossi, M. (2002). A Century of Change: The US Labor Force, 1950-2050. Monthly Lab. Valasek (eds.), Gender and Security Sector Reform Toolkit, DCAF, UNINSTRAW, OSCE/ODIHR, Geneva.

Women's Economic Participation and Empowerment Status Report (2016). Centre of Gender and Policy Studies and UN-Women, NCSW Publication, Pakistan.

World Economic Forum (2017). The Global Gender Gap Report 2017, World Bank Publication. Retrieved from: https://www.weforum.org/reports/the-global-gendergap-report-2017 on August 21, 2018.

Zia, M. (2013). Elections-women's representation in legislatures, Aurat Foundation and Legislative Watch Publication, Pakistan.

Mussarat Jabeen is Ph.D Scholar in the Centre of Excellence for Women's Studies, University of Karachi.

Dr. Nasreen Aslam Shah is Dean, Faculty of Arts and Social Sciences, University of Karachi, Meritorious Professor in the Department of Social Work and Director, Centre of Excellence for Women's Studies, University of Karachi.

Faraz Ahmed Wajidi is an Associate Professor in the Jinnah Post Graduate Medical Centre, Karachi. 